\title{
A Heat-sensitive Lysis Mutant of Bacillus subtilis 168 with a Low Activity of Pyruvate Carboxylase
}

\author{
By R. S. BUXTON \\ Division of Microbiology, National Institute for \\ Medical Research, Mill Hill, London NW7 1 AA
}

(Received 5 December 1977)

\begin{abstract}
A mutant of Bacillus subtilis which grew in complex medium at $30 \mathrm{C}$ but lysed at $45 \mathrm{C}$ has been isolated. It could only grow on minimal medium at $45^{\circ} \mathrm{C}$ with added aspartate $\left(20 \mu \mathrm{g} \mathrm{ml}^{-1}\right)$ but lysed if lysine $\left(20 \mu \mathrm{g} \mathrm{ml}^{-1}\right)$ was also present. The requirement for aspartate was due to a low activity of pyruvate carboxylase; the site of the mutation ( $p y c)$ was linked $\left(16^{\circ}\right.$ " cotransducible using phage PBS1) to the pyrD locus, and the order of markers deduced was: $p y r D-c y s C-p y c$. This defect appeared to lead to decreased synthesis of mesodiaminopimelic acid (meso $\mathrm{A}_{2} \mathrm{pm}$ ), an amino acid unique to peptidoglycan and its precursors. At the restrictive temperature the mutant accumulated uridine- $5^{\prime}$-diphosphate $\mathrm{N}$-acetylmuramyl-L-alanyl-D-glutamate, since meso $\mathrm{A}_{2} \mathrm{pm}$ is the next amino acid to be added to the growing peptide chain of peptidoglycan. This resulted in an inhibition of peptidoglycan synthesis, determined as a reduced incorporation of $\mathrm{N}$-acetyl $\left[{ }^{14} \mathrm{C}\right]$ glucosamine. Peptidoglycan synthesis was not decreased if the mutant was grown in media containing aspartate but lacking lysine.

The sensitivity to lysine may arise because (i) at $45^{\circ} \mathrm{C}$ the mutant was starved for aspartate and hence meso $\mathrm{A}_{2} \mathrm{pm}$ even when aspartate was present, since aspartate utilization, as estimated by the incorporation of $\left[{ }^{3} \mathrm{H}\right]$ aspartate into trichloroacetic acid precipitable material, was relatively inefficient; and (ii) this diminished level of meso $\mathrm{A}_{2} \mathrm{pm}$ synthesis from aspartate was further curtailed since lysine inhibits one of the aspartokinases in $B$. subtilis. Thus, addition of lysine allowed protein synthesis and hence autolysin production to proceed whilst peptidoglycan synthesis remained inhibited.

When autolysis was blocked, either indirectly by stopping protein synthesis through starvation of aspartate and lysine, or directly by introducing a lyt mutation, then shifting the mutant to $45^{\circ} \mathrm{C}$ did not result in lysis but growth still ceased.
\end{abstract}

\section{INTRODUCTION}

To study the control of the biosynthesis of the major structural bacterial wall polymer, peptidoglycan, heat-sensitive mutants defective in its synthesis have been isolated in Escherichia coli (e.g. Matsuzawa et al., 1969; Lugtenberg, de Haas-Menger \& Ruyters, 1971) and in Staphylococcus aureus (Chatterjee \& Young, 1972; Good \& Tipper, 1972). These mutants lysed at the non-permissive temperature since peptidoglycan, which resists the force produced by the osmotic pressure of the bacterium across the cytoplasmic membrane, was no longer made. In a number of these mutants specific defects in the enzymes involved in peptidoglycan synthesis have been identified.

In this communication I describe a heat-sensitive lysis mutant of Bacillus subtilis which lysed, not because it had a defect in peptidoglycan synthesis itself, but because it appeared to have a decreased level of meso-diaminopimelic acid (meso $\left.\mathrm{A}_{2} \mathrm{pm}\right)$ synthesis owing to a lowered activity of pyruvate carboxylase. 


\section{Table 1. Bacterial strains used}

\begin{tabular}{|c|c|c|}
\hline Strain & Genotype & Origin or reference \\
\hline 168 & $\operatorname{trp} C 2$ & Buxton (1976) \\
\hline 168thy & $\operatorname{trp} C 2$ thy $A$ thy $B$ & Buxton (1976) \\
\hline RB 1476 & trpC2 thy A thy B pyc: & EMS-induced mutant of 168 \\
\hline $\mathrm{M} 22$ & purA 16 leuA8 metBS ilvAl & Buxton (1976) \\
\hline $\mathrm{RB} 1950$ & purAl6 metBS ilvAl pyc & DNA.RB1476 $\times$ M $22 \rightarrow$ Leu \\
\hline MB50 & pyrDI* cysC7 & P. J. Piggot \\
\hline FJ3 & $\operatorname{metc} 3$ lyt -1 & J. E. Fein \\
\hline RBI117 & purA 16 met $B 5$ pyc $1 y_{i}-1$ & DNA.FJ $3 \times$ RB $1950 \rightarrow 11 v A$ \\
\hline
\end{tabular}

* pyrDl is the 1 ra-l marker (Potvin, Kelleher \& Gooder, 1975) which was mapped relative to cysC and fir $A$ by Young (1975).

\section{MITHODS}

Bacterial strains. The derivatives of B. subtilis 168 are shown in Table 1.

Media and chemicals. L-broth, Spizizen's min mal medium and MS minimal medium have all been described previously (Buxton, 1976). CH/S/C was a casein acid-hydrolysate medium (Janczura, Perkins \& Rogers, 1961). Difco Bacto Casamino acids [present at $1.0 \%(\mathrm{w} / \mathrm{v})$ in medium $\mathrm{CH} / \mathrm{S} / \mathrm{C}$ ] contained $0.5 \%$ $(\mathrm{w} / \mathrm{w})$ aspartic acid and $7.0 \%(\mathrm{w} / \mathrm{w})$ lysine (H. Saunders, personal communication). Wall medium was $0.1 \mathrm{M}-\mathrm{KH}_{2} \mathrm{PO}, / \mathrm{Na}_{2} \mathrm{HPO}_{4}$ buffer, $\mathrm{pH} 7 \cdot 3$, containing: $\mathrm{MgSO}_{4}, 2 \mathrm{~mm}$; glucose, $0.5 \%$ (w/v); chloramphenicol (Parke-Davis, Hounslow, Middlesex), $50 / \mathrm{g} \mathrm{ml}^{-1} ; \mathrm{N}$-acetylglucosamine, $0.15 \mathrm{~mm}$; L-arginine, $0.2 \%(\mathrm{w} / \mathrm{v})$; and DL-alanine, $0.02 \%(\mathrm{w} / \mathrm{v})$. Schaeffer's sporulation agar was as described by Schaeffer, Millet \& Aubert (1965).

Radioactively labelled compounds were obtained from The Radiochemical Centre, Amersham.

Mutant isolation. The isolation of the mutant strain RB1476 from the parent strain 168thy, after mutagenesis with ethyl methanesulphonate (EMS), has been described (Buxton, 1976). Briefly, heat-sensitive mutants were screened in L-broth for those which showed visible lysis after a period ( $3 \mathrm{~h}$ or overnight) at the non-permissive temperature, $45^{\circ} \mathrm{C}$. The mutation giving rise to this phenotype was transferred to strain M22 (leuA) by DNA-mediated transformation using a saturating concentration of DNA (congression) and selecting for Leu recombinants. The experiments described in this paper were performed on one such recombinant (strain RB 1950), its parent (M22) and a Lyt ${ }^{-3}$ recombinant (RBII17, see below).

Enzyme assays. Sonic extracts were prepared from cells grown in L-broth. Glutamate-oxaloacetate transaminase [L-aspartate: 2-oxoglutarate aminotransferase; EC 2.6.1.1] was assayed by measuring the formation of oxaloacetate spectrophotometricaly (Gunsalus \& Stamer, 1955); pyruvate carboxylase [pyruvate: carbon-dioxide ligase (ADP-forming); EC 6.4.1.1] was assayed by coupling the reaction to malate dehydrogenase (Sigma) and following the rate of NADH oxidation spectrophotometrically (Seubert \& Weiker, 1969). The enzyme assays were performed using a Unicam SP800 recording spectrophotometer. Like pyruvate carboxylase from Pseudomonas citronellolis, but unlike the enzyme from liver, yeast or Arthrobacter globiformis (see Kornberg, 1966), the B. subtilis enzyme did not appear to require acetyl-CoA for its activity (unpublished data). Protein was determined by the method of Lowry et al. (1951).

Estimation of peptidoglycan synthesis. Bacteria were grown overnight with aeration at $30{ }^{\circ} \mathrm{C}$ in $\mathrm{CH} / \mathrm{S} / \mathrm{C}$ medium containing: $N$-acetylglucosamine, $0.5 \mathrm{~mm} ; \mathrm{MgSO}_{4}, 3.3 \mathrm{~mm}$; isoleucine, leucine and methionine, each at $20 \mu \mathrm{g} \mathrm{ml}^{-1}$; and adenine, $40 / \mathrm{g} \mathrm{ml}^{-1}$. The cultures were then diluted into similar medium, with added glucose $(0.4 \%, \mathrm{w} / \mathrm{v})$, and grown with aeration at $30{ }^{\circ} \mathrm{C}$ until an absorbance of approximately 0.8 at $600 \mathrm{~nm}$ was reached. An absorbance of 1.0 was equivalent to $300 \mu \mathrm{g}$ dry weight $\mathrm{ml}^{-1}$. Cultures $(30 \mathrm{ml})$ were harvested by centrifugation at $35^{\circ} \mathrm{C}$ and resuspended in wall medium $(20 \mathrm{ml})$ pre-warmed to $30^{\circ} \mathrm{C}$; samples $(10 \mathrm{ml})$ were then incubated at $30^{\circ} \mathrm{C}$ or $45^{\circ} \mathrm{C}$ for $10 \mathrm{~min}$. $N$-Acetyl-D- $\left[1-{ }^{14} \mathrm{C}\right] \mathrm{glucosamine}(0 \cdot 2 / / \mathrm{Ci}$, $\left.58 \mathrm{mCi} \mathrm{mmol}^{-1}\right)$ was added to each $10 \mathrm{ml}$ culture and samples $(0.5 \mathrm{ml})$ were taken at intervals into $0.5 \mathrm{ml}$ ice-cold $10 \%(\mathrm{w} / \mathrm{v})$ trichloroacetic acid (TCA). After storage on ice for at least $15 \mathrm{~min}$, the samples were heated at $80^{\circ} \mathrm{C}$ for $15 \mathrm{~min}$ to remove teichoic acid, and then filtered under vacuum through glass-fibre filters (Whatman GF/C). The filters were washed successively with cold $5 \%(\mathrm{w} / \mathrm{v}) \mathrm{TCA}$, ethanol and ether, dried and immersed in $2 \mathrm{ml}$ scintillation fluid [toluene containing 2,5-diphenyloxazole $(0 \cdot 4 \%, \mathrm{w} / \mathrm{v})$ and 1,4-bis-(4-methyl-5-phenyloxazol-2-yl)benzene $(0.01 \%, \mathrm{w} / \mathrm{v})]$ and counted for radioactivity in a Packard Tri-Carb liquid-scintillation spectrometer. Pooley (1976) has shown that the measurement of $N$-acetyl $\left[{ }^{14} \mathrm{C}\right]-$ glucosamine incorporation in this manner is a valid estimation of peptidoglycan synthesis.

Isolation and characterization of nucleotide-bound peptidoglycan precursors. After $90 \mathrm{~min}$ in wall medium as described above, the culture $(7.0 \mathrm{ml})$ was centrifuged at $4{ }^{\circ} \mathrm{C}$, and the bacteria were resuspended in 


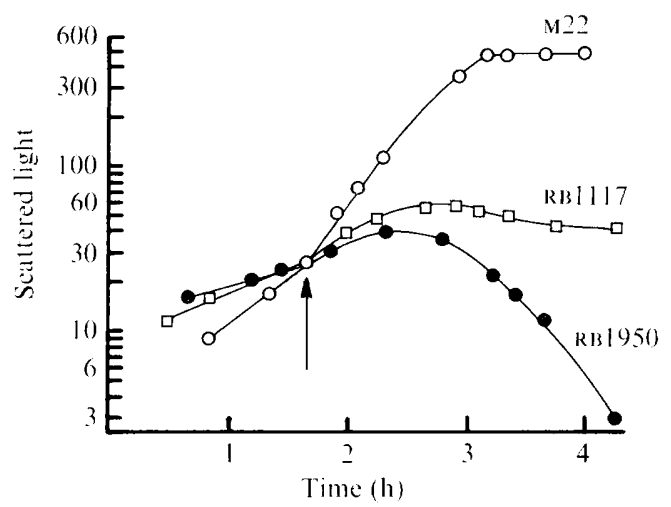

Fig. 1. Effect of a temperature shift on the growth of B. subtilis strains M22 (wild-type), RB 1950 $(p y c)$ and $\mathrm{RB} 1117$ ( $p y c / y t)$. Bacteria were grown with aeration (bubbling) in MS medium containing Casamino acids at $30^{\circ} \mathrm{C}$ and shifted to $45^{\circ} \mathrm{C}$ at the time indicated by the arrows. Growth was monitored using an EEL nephelometer (see Buxton, 1976). A scattered light reading of 100 corresponds to a viable count of $6 \times 10^{8}$ bacteria $\mathrm{ml}^{-1}$.

$0 \cdot 1$ vol. distilled water. This suspension was heated at $100^{\circ} \mathrm{C}$ for $5 \mathrm{~min}$, centrifuged and the supernatant liquid was retained. The pellet was washed again with $0.5 \mathrm{ml}$ water, centrifuged, and the supernatants were pooled, freeze-dried and taken up in $0.1 \mathrm{ml}$ water. This solution was chromatographed on Whatman no. 1 paper for approximately $3 \mathrm{~d}$. Descending chromatography was carried out in the solvent system: isobutyric acid/0.5- $\mathrm{M}-\mathrm{NH}_{3}(5: 3, \mathrm{v} / \mathrm{v})$, and nucleotides were located by their absorption of ultraviolet light. Peptidoglycan precursors were identified by reference to the position of known precursors (see Ward, 1975) and by amino acid analysis.

Amino acid analysis and the determination of the bound $N$-acetylhexosamine content of nucleotide precursors was determined as described by Ward (1975). Radioactivity on paper was determined by autoradiography and counted directly in a Packard Tri-Carb liquid-scintillation spectrometer (see Ward, 1975).

Incorporation of aspartate and lysine. Bacteria were grown in MS medium containing aspartate and lysine (each at $20 \mu \mathrm{g} \mathrm{ml}{ }^{-1}$ ) at $35^{\circ} \mathrm{C}$ until an absorbance at $600 \mathrm{~nm}$ of $0 \cdot 2$ to 0.3 was reached. L- [G- $\left.{ }^{3} \mathrm{H}\right] \mathrm{Aspartic}$ acid $\left(1.1 \mathrm{Ci} \mathrm{mmol}^{-1}, 25 \mu \mathrm{Ci}\right)$ and DL- $\left[4,5(\mathrm{n}){ }^{3} \mathrm{H}\right]$ lysine monohydrochloride $\left(10 \mathrm{Ci} \mathrm{mmol}{ }^{-1}, 25 \mu \mathrm{Ci}\right)$ were added to separate $10 \mathrm{ml}$ cultures, and samples $(0.5 \mathrm{ml})$ were taken at intervals into $0.5 \mathrm{ml}$ ice-cold $10 \%$ $(w / v)$ TCA. After storage on ice, the samples were filtered, treated, and counted as described above.

Genetical methods. Transduction using phage PBSI and DNA-mediated transformation have been described previously (Buxton, 1976).

The pyc lyt recombinant strain RB 1117 was isolated by transforming strain RB 1950 with a saturating amount of DNA isolated from the autolytic enzyme-deficient mutant FJ3 (Fein \& Rogers, 1976) and selecting for IlvA: recombinants. Amongst these, lyt recombinants were identified by their tendency to form long chains of bacteria as seen under the phase contrast microscope. Their $\mathrm{Lyt}^{-}$phenotype was confirmed by testing for lysis of whole bacteria at $\mathrm{pH} 8.5$ at $45^{\circ} \mathrm{C}$ (unpublished data).

\section{RESULTS}

\section{Growth characteristics of mutant strain $\mathrm{RB} 1950$}

A culture of the mutant strain $\mathrm{RB} 1950$, when shifted from $30^{\circ} \mathrm{C}$ to $45^{\circ} \mathrm{C}$ in MS medium containing Casamino acids $(1 \%, \mathrm{w} / \mathrm{v}$ ), began to lyse after $60 \mathrm{~min}$ (Fig. 1). At $30 \mathrm{C}, \mathrm{M} 22$ had a doubling time of $32 \mathrm{~min}$, whereas that for RB1950 was $76 \mathrm{~min}$. Strain RB 1950 grew at $45 \mathrm{C}$ on Spizizen's minimal medium with glucose as carbon source if aspartate $(20 \mu \mathrm{g}$ $\mathrm{ml}^{-1}$ ) was added, but not if an equal amount of lysine was also added, or if lysine and threonine $\left(20 \mu \mathrm{g} \mathrm{ml}^{-1}\right)$ were also added. It did, however, grow on medium containing aspartate $\left(200 \mu \mathrm{g} \mathrm{ml}^{-1}\right)$ and lysine $\left(20 \mu \mathrm{g} \mathrm{ml}^{-1}\right)$. The mutant also grew on minimal glucose medium at $45 \mathrm{C}$ if malate $\left(40 \mu \mathrm{g} \mathrm{ml}^{-1}\right)$ or glutamate $\left(20 \mu \mathrm{g} \mathrm{ml}^{-1}\right)$ were added, although not if 2-oxoglutarate $\left(40 \mu \mathrm{g} \mathrm{ml}^{-1}\right)$ or succinate $\left(20 \mu \mathrm{g} \mathrm{ml}^{-1}\right)$ were substituted (this may have been because the latter compounds have difficulty in entering the bacterium; 2-oxoglutarate is also somewhat unstable). No other amino acid addition (including $\mathrm{A}_{2} \mathrm{pm}$ and D-alanine) 


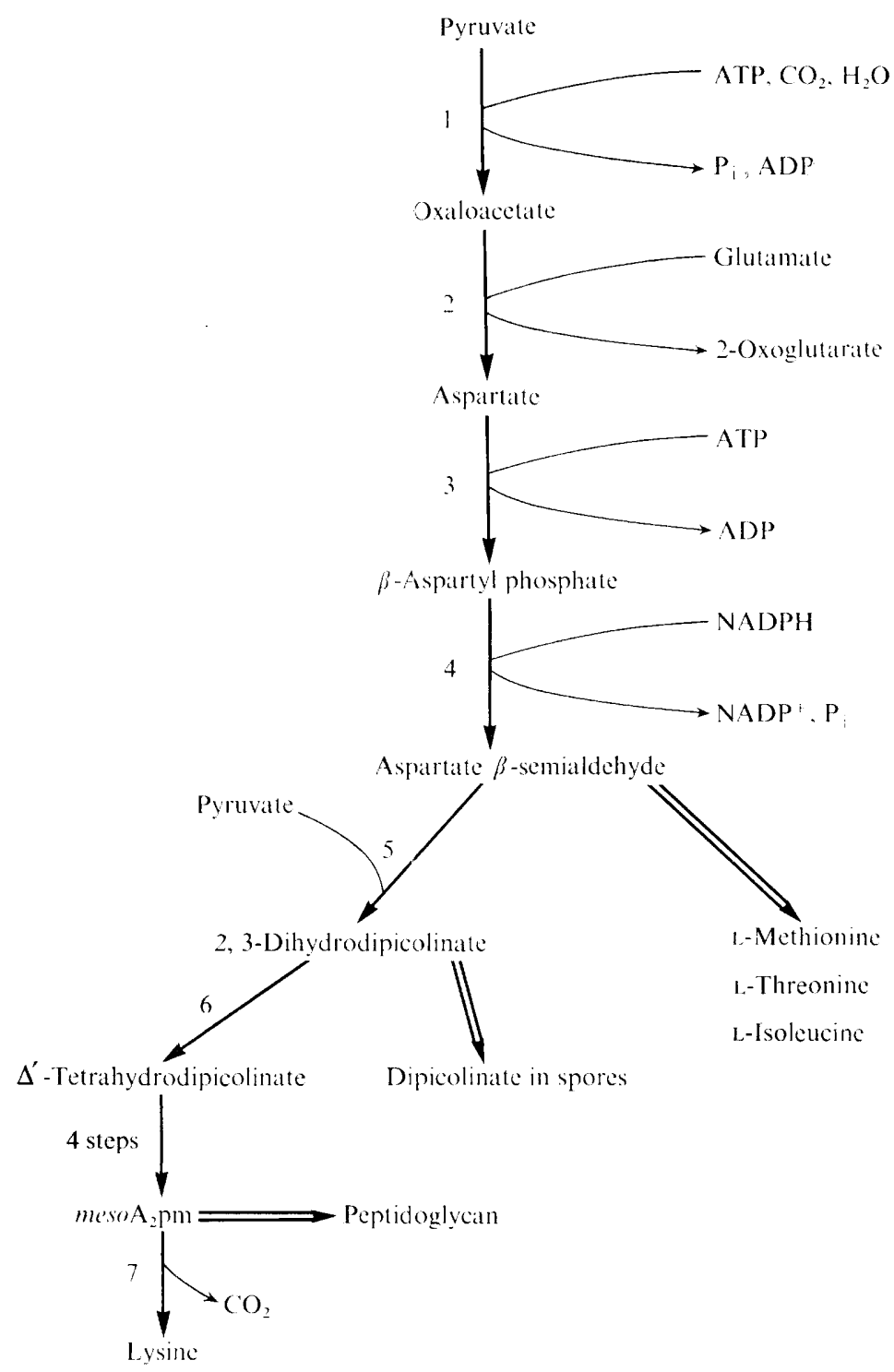

Fig. 2. Pathways leading to the synthesis of L-lysine. Not all intermediate steps are shown. The enzymes numbered are: 1, pyruvate carboxylase (EC 6.4.1.1); 2, glutamate-oxaloacetate transaminase (EC 2.6.1.1); 3, aspartokinase (EC 2.7.2.4); 4, aspartate- $\beta$-semialdehyde dehydrogenase (EC 1.2.1.11); 5, dihydrodipicolinate synthase (EC 4.2.1.52); 6, dihydrodipicolinate reductase (EC 1.3.1.aa); 7, diaminopimelate decarboxylase (EC 4.1.1.20).

allowed growth at $45^{\circ} \mathrm{C}$. At $30^{\circ} \mathrm{C}$, growth occurred on minimal glucose agar except if lysine $\left(20 \mu \mathrm{g} \mathrm{ml}^{-1}\right)$ alone was added, although again protection was afforded by an equal amount of aspartate.

\section{Enzyme defect of the mutant}

The growth characteristics suggested there may be a block in the synthesis of aspartate (see Fig. 2). No difference in iglutamate-oxaloacetate transaminase activity could be detected between strain RB 1950 and its parent $\mathrm{M} 22$, but a significant difference was noted in the specific activity of pyruvate carboxylase. At an assay temperature of $45^{\circ} \mathrm{C}$, the specific 
Table 2. Genetic cross to determine the location of the pyc mutation

Phage PBSI was grown on strain RB1950 at $30^{\circ} \mathrm{C}$, and used to transduce strain MB 50 ( $p y r D /$ cysC 7 ) to PyrD ${ }^{+}$on minimal plates containing cysteine and aspartate (each at $20 \mu \mathrm{g} \mathrm{m}^{-1}$ ) at $30{ }^{\circ} \mathrm{C}$. After purification by single colony isolation, the recombinants were scored as cys or cys at $30^{\circ} \mathrm{C}$ on agar plates lacking cysteine, and as $p y c^{+}$or $p y c$ on L-broth plates at $45^{\circ} \mathrm{C}$ and on minimal plates lacking aspartate at $45{ }^{\circ} \mathrm{C}$. There was $100 \%$ correlation of $p y c^{+}$and $p y c$ as scored on L-broth plates and on minimal plates lacking aspartate. On the latter plates pyc recombinants grew a little, but lysed.

\begin{tabular}{lccc}
$\begin{array}{c}\text { Selected } \\
\text { marker }\end{array}$ & \multicolumn{3}{c}{ Unselected markers } \\
pyrD & pyc & 32 & 35 \\
& pyc & 13 & 0
\end{tabular}

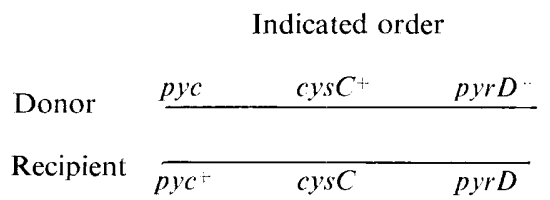

activity of the enzyme from strain RB 1950 grown at $30{ }^{\circ} \mathrm{C}$ in L-broth was $4.8 \mathrm{nmol} \mathrm{NADH}$ oxidized $\mathrm{min}^{-1}$ (mg protein) ${ }^{-1}$, whereas from strain $\mathrm{M} 22$, it was 120 . At an assay temperature of $30 \mathrm{C}$, the specific activities were 17 for RB 1950 and 50 for M22. Thus strain RB 1950 had $33 \%$ of the pyruvate carboxylase activity of $\mathrm{m} 22$ when assayed at $30 \mathrm{C}$ and only $4 \%$ at $45{ }^{\circ} \mathrm{C}$. It therefore had a heat-sensitive pyruvate carboxylase, the mutation being somewhat leaky at $30 \mathrm{C}$. This was also indicated by a requirement for very great aeration (by shaking) at $30 \mathrm{C}$ to avoid lysis, which may reflect the need for a continuous supply of $\mathrm{CO}_{2}$ to enable the lower amount of pyruvate carboxylase to function at its maximal rate.

The inability of the mutant to grow on minimal glucose medium except when utilizable intermediates of the tricarboxylic acid cycle (or their precursors) were added, suggested that the mutant lacked the anaplerotic enzyme, pyruvate carboxylase, for growth on $\mathrm{C}_{3}$ compounds (see Kornberg, 1966). In the Enterobacteriaceae, mutants lacking the analogous enzyme, phosphenolpyruvate carboxylase, have similar nutritional phenotypes (Theodore \& Englesberg, 1962; Amarasingham, 1959; Ashworth \& Kornberg, 1963).

\section{Genetic analysis of the mutant}

Phage-mediated transduction using PBSI showed that the site of the mutation $(p y c)$ giving rise to the heat-sensitive phenotype of strain RB1950 was $16 \%$ cotransducible with pyrDl. From the three-point cross shown in Table 2, the order of markers was deduced to be $p y r D 1-c y s C-p y c$, assuming that recombinants requiring a minimum of four exchanges between donor and recipient DNA will occur significantly less frequently than those requiring a minimum of two. [Young (1975) has mapped pyrD and $c y s C$ relative to other markers.] pyc was therefore very probably identical to the asp $A$ locus, a mutant of which has previously been shown to be defective in pyruvate carboxylase (Hoch \& Mathews, 1972). The aspA locus was closely linked to recAI (Hoch \& Mathews, 1972), a position which is compatible with the mapping described above (see Lepesant-Kejzlarovà et al., 1975). [The symbol $p y c$ is used here to avoid confusion since asp $A$ in $E$. coli has been used for aspartase; see Bachmann, Low \& Taylor (1976).]

The mutant had difficulty in sporulating, presumably because it was starved of $\mathrm{A}_{2} \mathrm{pm}$ and dipicolinic acid. However, when the few spores produced on Schaeffer's sporulation agar germinated, they gave rise to heat-resistant organisms that grew at $45^{\circ} \mathrm{C}$ on complex medium, and no longer required aspartate. Thus the lysis phenotype and aspartate requirement are most probably due to a single mutation. 
Table 3. Accumulation of UDP-MurNAc-dipeptide by the mutant strain RB 1950

Mutant strain RB 1950 and its parent $\mathrm{M} 22$ were grown at $30^{\circ} \mathrm{C}$ in $\mathrm{CH} / \mathrm{S} / \mathrm{C}$ (see Methods) and resuspended in wall medium. After $10 \mathrm{~min}$ incubation, $N$-acetyl-D- $\left[1-{ }^{14} \mathrm{C}\right] \mathrm{glucosamine}$ was added, and after $90 \mathrm{~min}$ the bacteria were harvested and the nucleotide-bound precursors of peptidoglycan were isolated and identified as described in Methods.

\begin{tabular}{|c|c|c|c|c|}
\hline & \multicolumn{2}{|c|}{ Strain $\mathrm{M} 22$} & \multicolumn{2}{|c|}{ Strain RB 1950} \\
\hline & $30^{\circ} \mathrm{C}$ & $45^{\circ} \mathrm{C}$ & $30{ }^{\circ} \mathrm{C}$ & $45 \mathrm{C}$ \\
\hline $\begin{array}{l}\text { Radioactivity co-chromatographing with } \\
\text { UDP-MurNAc-L-Ala-D-Glu (c.p.m.) }\end{array}$ & 349 & 1184 & 300 & 5969 \\
\hline $\begin{array}{l}\text { Total radioactivity in heat-resistant TCA- } \\
\text { precipitable material (peptidoglycan) (c.p.m.) }\end{array}$ & 19390 & 49028 & 18578 & 12376 \\
\hline $\begin{array}{l}\text { Radioactivity in } \\
\text { UDP-MurNAc-L-Ala-1-Glu as a } \\
\text { percentage of the total radioactivity in } \\
\text { peptidoglycan }\end{array}$ & $1 \cdot 8$ & $2 \cdot 4$ & $1 \cdot 6$ & $48 \cdot 2$ \\
\hline
\end{tabular}

\section{Synthesis of peptidoglycan and accumulation of nucleotide-bound peptidoglycan precursors}

Since aspartate is the precursor of meso $\mathrm{A}_{2} \mathrm{pm}$ (see Fig. 2) and D-glutamate, it seemed likely that lysis at $45{ }^{\circ} \mathrm{C}$ was due to a starvation of meso $\mathrm{A}_{2} \mathrm{pm}$ and D-glutamate and a consequent lowering of the rate of peptidoglycan synthesis, since D-glutamate and meso $\mathrm{A}_{2} \mathrm{pm}$ are the second and third amino acids to be added to the peptide side-chain of peptidoglycan (see review by Ghuysen \& Shockman, 197.3). If this were so, it should be possible to detect, at $45 \mathrm{C}$, the accumulation of peptidoglycan precursors. Cultures of strain RB 1950 and its parent $\mathrm{M} 22$ were grown at $30 \mathrm{C}$ in $\mathrm{CH} / \mathrm{S} / \mathrm{C}$ as described in Methods, resuspended in wall medium [which lacks aspartate and contains chloramphenicol to stop protein synthesis and thus inhibit lysis whilst allowing peptidoglycan synthesis to continue (Hughes, Tanner \& Stokes, 1970)], and incubated at $30^{\circ} \mathrm{C}$ or $45^{\circ} \mathrm{C}$. After $10 \mathrm{~min} \mathrm{~N}$-acetyl $\left[{ }^{14} \mathrm{C}\right]$ glucosamine was added, and after $90 \mathrm{~min}$ the bacteria were harvested and the nucleotide-bound precursors of peptidoglycan were isolated and identified as described in Methods. Strain M22 incorporated approximately $2 \cdot 5$ times more $N$-acetyl $\left[{ }^{14} \mathrm{C}\right]$ glucosamine into peptidoglycan after 90 min at $45 \mathrm{C}$ than at $30^{\circ} \mathrm{C}$. In contrast, strain $\mathrm{RB} 1950$ incorporated slightly less at $45^{\circ} \mathrm{C}$ than at $30 \mathrm{C}$. Thus the mutant made less peptidoglycan at $45^{\circ} \mathrm{C}$. When the experiment was performed in wall medium supplemented with aspartate $\left(200 \mu \mathrm{g} \mathrm{ml} l^{-1}\right)$, $\mathrm{N}$-acetyl $\left[{ }^{14} \mathrm{C}\right]$ glucosamine incorporation into peptidoglycan at $45^{\circ} \mathrm{C}$ by strain $\mathrm{RB} 1950$ was nearly as great as by strain $\mathrm{m} 22$.

The accumulation of peptidoglycan precursors after $90 \mathrm{~min}$ in wall medium is shown in Table 3. The mutant strain RB1950, unlike its parent $\mathrm{M} 22$, accumulated UDP- $N$-acetylmuramyl-L-alanyl-D-glutamic acid, the identity of which was established by amino acid analysis (kindly performed by Dr J. B. Ward). In RB1950 at $45 \mathrm{C}, 48 \%$ of the total radioactivity in heat-resistant TCA-precipitable material was in UDP-MurNAc-L-Ala-D-Glu, whereas this figure was $2.4 \%$ in the parent $\mathrm{M} 22$ (Table 3 ). The mutant accumulated $3.15 \mu \mathrm{mol}$ of UDP-MurNAc-dipeptide per $100 \mathrm{mg}$ dry weight of bacteria, compared with $2 \cdot 17 \mu \mathrm{mol}$ accumulated by a stable L-form of $B$. subtilis defective in aspartate- $\beta$-semialdehyde dehydrogenase and $0 \cdot 13 \mu \mathrm{mol}$ accumulated by wild-type $B$. subtilis (Ward, 1975).

Thus the defect in pyruvate carboxylase appeared to lead to lower meso $\mathrm{A}_{2} \mathrm{pm}$ synthesis, slowing peptidoglycan synthesis and resulting in the accumulation of UDP-MurNAcL-Ala-D-Glu. The presence of aspartate allowed peptidoglycan synthesis to proceed in the mutant at nearly the same rate as in the wild type.

However, since the defect in pyruvate carboxylase activity results in decreased ability to make oxaloacetate (and hence aspartate and $\mathrm{A}_{2} \mathrm{pm}$ ), glutamate synthesis will also be impaired because oxaloacetate (with acetyl-CoA) is also its precursor. Thus, it seems strange 


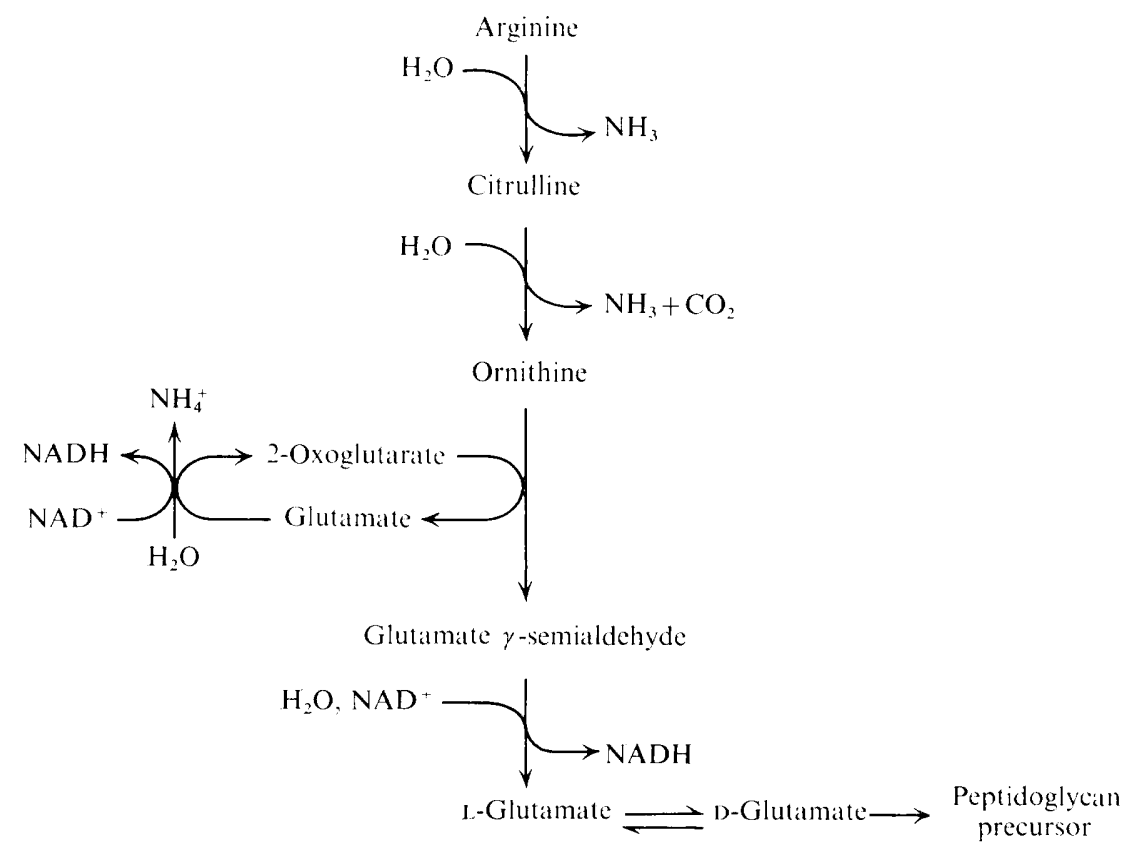

Fig. 3. Possible pathway for the provision of glutamate for peptidoglycan formation.

that UDP-MurNAc-L-Ala-D-Glu was accumulated rather than UDP-MurNAc-L-Ala, unless oxaloacetate were specifically channelled to glutamate. One explanation could be that a limited supply of glutamate is formed by breakdown of arginine in the wall medium (Fig. 3), and this limited supply of glutamate is used for peptidoglycan formation rather than as a precursor of aspartate (i.e. glutamate $\rightarrow 2$-oxoglutarate $\rightarrow$ succinate $\rightarrow$ fumarate $\rightarrow$ malate $\rightarrow$ oxaloacetate $\rightarrow$ aspartate).

\section{Sensitivity of the mutant to lysine}

The lysis of the mutant at $45^{\circ} \mathrm{C}$ in complex medium may be due to its sensitivity to the lysine present in the medium, since it failed to grow on minimal medium containing both aspartate and lysine, although increasing the aspartate concentration afforded some protection. This sensitivity to lysine may be due to several effects.

1. Bacillus subtilis strain 168 appeared to incorporate aspartate from medium containing lysine and aspartate into TCA-precipitable material much less efficiently than lysine (Fig. 4). Similar results were obtained with strain M22, whether or not lysine was present (data not shown). This could be due either to an inefficient mechanism for uptake of aspartate or to its degradation.

2. The decreased level of $m e s o \mathrm{~A}_{2} \mathrm{pm}$ synthesis would be further curtailed when lysine was added because lysine inhibits one of the two aspartokinases of $B$. subtilis (aspartokinase II) (Hampton et al., 1971; Rosner \& Paulus, 1971; see Fig. 2); this would lead to a decrease in the rate of synthesis of $\beta$-aspartyl phosphate and hence of meso $\mathrm{A}_{2} \mathrm{pm}$ and peptidoglycan. The action of diaminopimelate decarboxylase is not reversible; meso $_{2} \mathrm{pm}_{\text {cannot therefore }}$ be synthesized from lysine (Rosner, 1975). [meso $\mathrm{A}_{2}$ pm-requiring mutants of $E$. coli have also been reported to lyse in the presence of lysine (Meadow, Hoare \& Work, 1957); this lysis was prevented by increasing the $\mathrm{A}_{2} \mathrm{pm}$ concentration of the medium.]

3. When aspartokinase II was inhibited by lysine, peptidoglycan synthesis may have been slowed more rapidly by $m e s o \mathrm{~A}_{2} \mathrm{pm}$ starvation than protein synthesis by threonine starvation. (Since threonine was present in excess, starvation for this amino acid may not 


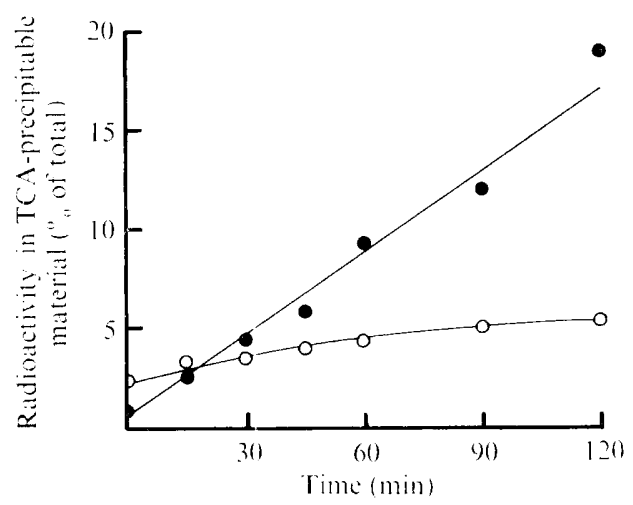

Fig. 4. Incorporation of $\left[{ }^{3} \mathrm{H}\right]$ aspartate $(O)$ and $\left[{ }^{3} \mathrm{H}\right]$ lysine $(0)$ into TCA-precipitable material by B. subtilis strain 168 . The strain was grown at $35^{\circ} \mathrm{C}$ in MS medium containing aspartate and lysine as described in Methods. $\left[{ }^{3} \mathrm{H}\right]$ Aspartate or $\left[{ }^{3} \mathrm{H}\right]$ lysine was then added, and samples were taken at intervals and assayed for the amount of radioactivity in TCA-precipitable material. Results are expressed as a percentage of the total radioactivity in the medium.
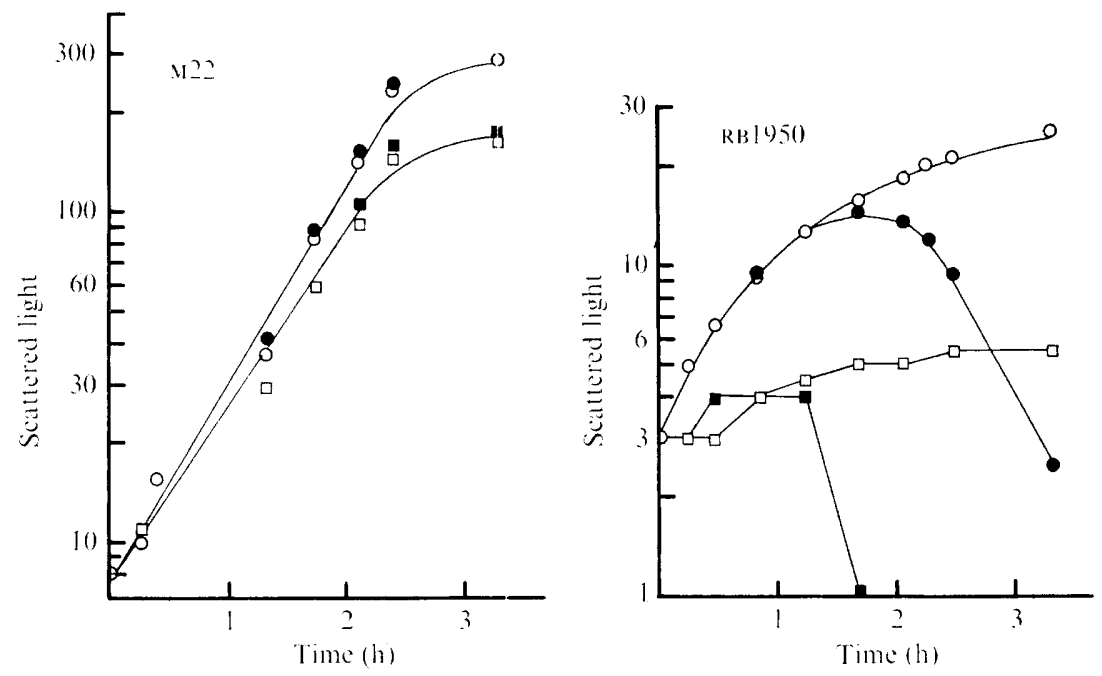

Fig. 5. Temperature shift experiments involving amino acid starvation, with $B$. subtilis strains M22 (wild-type) and RB1950 (pyc). Strains v22 and RB1950, each in MS medium containing methionine, isoleucine, leucine and aspartate $\left(20 \mu \mathrm{g} \mathrm{ml}^{-1}\right.$ each $)$ and adenine $\left(40 \mu \mathrm{g} \mathrm{ml}^{-1}\right)$, were grow'n with aeration at $30^{\circ} \mathrm{C}$ to exponential phase, then harvested by centrifugation at room temperature, washed in MS medium lacking aspartate, and resuspended in MS medium lacking aspartate $(\square)$, or supplemented with aspartate $(\bigcirc)$ or lysine $(\square)$ or aspartate plus lysine (๑), each at $20 \mu \mathrm{g}$ $\mathrm{ml}^{-1}$. At time 0 , the cultures were shifted to $45^{\circ} \mathrm{C}$ and aerated, and growth was followed using an EEL nephelometer. A scattered light reading of 100 corresponds to a viable count of $6 \times 10^{8}$ bacteria $\mathrm{ml}^{-1}$.

have occurred. The strain used was auxotrophic for methionine and isoleucine which were present in the medium.) Protein synthesis, and hence autolysis, would then overtake peptidoglycan synthesis resulting in lysis.

If protein synthesis, and hence autolysin production, were to be slowed at the same time as peptidoglycan synthesis, lysis would not be expected to occur. This is demonstrated by the results shown in Fig. 5 . When the mutant was shifted to $45^{\circ} \mathrm{C}$ in minimal medium lacking aspartate and lysine, it stopped growing but did not lyse; in medium containing 
lysine, however, the mutant lysed, as it did somewhat later in medium containing aspartate and lysine. Raising the aspartate and lysine concentrations each to $200 \mu \mathrm{g} \mathrm{ml}^{-1}$ allowed growth to continue for a much longer time before lysis began (data not shown) - this probably enabled more aspartate to be utilized and peptidoglycan synthesis to proceed for a longer time. The addition of lysine to the wild-type strain M22 did not cause lysis, presumably because such bacteria were not starved for $m e s o \mathrm{~A}_{2} \mathrm{pm}$.

Direct inactivation of the autolytic enzymes would also be expected to inhibit lysis but the mutant would still be unable to grow even in complex medium containing aspartate because of meso $\mathrm{A}_{2} \mathrm{pm}$ starvation. In fact, an autolytic-enzyme deficient derivative of strain $\mathrm{RB} 1950$ (strain RB1117, pyc lyt) lysed only slightly at $45^{\circ} \mathrm{C}$ in Casamino acid medium (Fig. 1), although growth did stop.

\section{DISCUSSION}

The isolation of heat-sensitive lysis mutants of $B$. subtilis may be expected to provide mutants blocked in the various stages of peptidoglycan synthesis (see review by Ghuysen \& Shockman, 1973). The isolation of a mutant blocked in $m e s o \mathrm{~A}_{2} \mathrm{pm}$ synthesis does not appear to be fortuitous, since the identification of some non-conditional osmotically fragile mutants (i.e. stable L-forms) as defective in aspartate- $\beta$-semialdehyde dehydrogenase activity (Ward, 1975) seems to indicate that this type of mutant is common amongst strains selected on this basis. Furthermore, I have isolated two other heat-sensitive lysis mutants which appear to have defects in meso $_{2} \mathrm{pm}$ synthesis (unpublished data); one is sensitive to lysine at $45^{\circ} \mathrm{C}$ but grows in its absence, and could have an altered aspartokinase.

The comparatively common occurrence of this type of lesion in meso $\mathrm{A}_{2} \mathrm{pm}$ synthesis amongst heat-sensitive lysis mutants may be due to the extremely autolytic nature of $B$. subtilis (Rogers \& Forsberg, 1971) compared with, for example, staphylococci (Rogers, 1967). Thus even a slight reduction in the rate of peptidoglycan synthesis allows wall synthesis to be rapidly overtaken by autolysis. The common occurrence of mutants blocked in $m_{e s o \mathrm{~A}_{2}} \mathrm{pm}$ synthesis may merely be a reflection of the large number of enzymes and hence genes, involved in this synthesis. It is, however, also tempting to think that since $m e s o \mathrm{~A}_{2} \mathrm{pm}$ is a unique constituent of peptidoglycan, its rate of synthesis may be the limiting factor determining the rate of peptidoglycan synthesis in bacilli. In the mutant studied in the present paper, it is also important that one of the aspartokinases is inhibited by lysine (Rosner \& Paulus, 1971). The aspartokinase of B. polymyxa, in contrast, is only inhibited by lysine plus threonine (Paulus \& Gray, 1964).

It may be possible to eliminate the class of mutants defective in meso $_{2} \mathrm{~A}_{2} \mathrm{pm}$ synthesis by selecting for lysis mutants in L-broth supplemented with $m e s o \mathrm{~A}_{2} \mathrm{pm}$, although this compound is only taken up poorly by $B$. subtilis 168 (data not shown). The results presented in this paper, however, suggest that if lysine is omitted, mutants blocked in meso $\mathrm{A}_{2} \mathrm{pm}$ synthesis will not lyse. A non-lytic mutant (Fein \& Rogers, 1976) as a parent strain could also be used to eliminate lysis mutants with only a slight reduction in the rate of peptidoglycan synthesis. Selection of secondary-site revertants of strain RB1950 which do not lyse at $45^{\circ} \mathrm{C}$ may in fact be a convenient selective procedure for the isolation of such nonlytic mutants.

Al-ssum \& White $(1977 a)$ have shown that in a Bacillus megaterium strain which has a biotin requirement at $37^{\circ} \mathrm{C}$, starvation of biotin resulted in abnormal morphology in the form of filaments, thin regions of wall, swollen ends and reduced ability to sporulate. The addition of aspartate restored normal morphology at $37^{\circ} \mathrm{C}$ even in the absence of biotin. Since biotin is required in the growth medium for maximal pyruvate carboxylase activity (Cazzulo, Sundaram \& Kornberg, 1969; Al-ssum \& White, 1977b), it seems that a similar phenotype to that of the $p y c$ mutant at $45^{\circ} \mathrm{C}$ may be achieved by inhibiting pyruvate carboxylase through biotin starvation. 
I thank Dr J. B. Ward for his valuable help and advice in the analysis of peptidoglycan synthesis, Mr P. N. Sockett and Mrs C. Curtis for their excellent technical assistance, and Professor H. J. Rogers and Dr Ward for their comments on the manuscript.

\section{REFERENCES}

Al-ssum, R. M. \& White, P. J. (1977a). Effects of biotin deficiency on growth, morphology and sporulation in Bacillus megaterium NCIB 7531 . Journal of General Microbiology 99, 343-351.

Al-ssum, R. M. \& White, P. J. (1977b). Activities of anaplerotic enzymes and acetyl coenzyme A carboxylase in biotin-deficient Bacillus megaterium. Journal of General Microbiology 100, 203-206.

AmARASINGHAM, C. R. (1959). The relative roles of malic enzyme and oxalacetic carboxylase in acetate oxidation. Federation Proceedings 18, 181.

Ashworth, J. M. \& KornberG, H. L. (1963). Fine control of the glyoxylate cycle by allosteric inhibition of isocitrate lyase. Biochimica et biophysica acta 73, 519-522.

Bachmann, B. J., Low, K. B. \& Taylor, A. L. (1976). Recalibrated linkage map of Escherichia coli K-12. Bacteriological Reviews 40, 116-167.

Buxron, R. S. (1976). Prophage mutation causing heat-inducibility of defective Bacillus subtilis bacteriophage PBSX. Journal of Virology 20, $22-28$.

Cazzulo, J. J., Sundaram, T. K. \& Kornberg, H. L. (1969). Regulation of pyruvate carboxylase formation from the apo-enzyme and biotin in a thermophilic bacillus. Nature, London 223. 1137-1138.

Chatterjee, A. N. \& Young, F. E. (1972). Regulation of the bacterial cell wall: isolation and characterisation of peptidoglycan mutants of Staphylococcus aureus. Journal of Bacteriology 111, 220-230.

Fein, J. E. \& Rogers, H. J. (1976). Autolytic enzyme-deficient mutants of Bacillus subtilis 168. Journal of Bacteriology 127, 1427-1442.

Ghuysen, J.-M. \& Shockman, G. D. (1973). Biosynthesis of peptidoglycan. In Bacterial Membranes and Walls, pp. 37-130. Edited by $\mathbf{L}$. Leive. New York: M. Dekker.

Good, C. M. \& Trpper, D. J. (1972). Conditional mutants of Staphylococcus aureus defective in cell wall precursor synthesis. Journal of Bacteriology 111, 231-241.

Gunsalus, I. C. \& Stamer, J. R. (1955). Transaminases in bacteria. Methods in Enzymology II, 170-177.

Hampton, M. L., McCormick, N. G., Behforouz', N. C. \& Freese, E. (1971). Regulation of two aspartokinases in Bacillus subtilis. Journal of Bacteriology 108, 1129-1134.

Hoch, J. A. \& Mathews, J. (1972). Genetic studies in Bacillus subtilis. In Spores, vol. V, pp. 113-116. Edited by $\mathbf{H}$. O. Halvorson, R. Hanson and L. L. Campbell. Washington, D.C.: American Society for Microbiology.

Hughes, R. C., Tanner, P. J. \& Stokes, E. (1970). Cell-wall thickening in Bacillus subtilis. Com. parison of thickened and normal walls. Bio chemical Journal 120, 159-170.

Janczura, E., Perkins, H. R. \& Rogers, H. J. (1961). Teichuronic acid: a mucopolysaccharide present in wall preparations from vegetative cells of Bacillus srubtilis. Biochemical Journal $\mathbf{8 0}$, 82-93.

KORNBERG, H. L. (1966). Anaplerotic sequences and their role in metabolism. Essays in Biochemistry 2, 1-31.

Lepesant-Kejzlarovà, J., Lepesant, J.-A., Walle, J., Billault, A. \& Dedonder, R. (1975). Revision of the linkage map of Bacillus subtilis 168: indications for circularity of the chromosome. Journal of Bacteriology 121, 823-834.

Lowry, O. H., Rosebrough, N. J., Farr, A. L. \& RANDALl, R. J. (1951). Protein measurements with the Folin phenol reagent. Journal of Biological Chemistry 193, 265-275.

Lugtenberg, E. J. J., de HaAs-Menger, L. \& RuYTERs, W. H. M. (1971). Murein synthesis and identification of cell wall precursors of temperature-sensitive mutants of Escherichia coli. Journal of Bacteriology 109, 326-335.

Matsuzawa, H., Matsuhashi, M., OKa, A. \& Sugrno, Y. (1969). Genetic and biochemical studies on cell wall peptidoglycan synthesis in Escherichia coli K-12. Biochemical and Biophysical Research Communications 36, 682-689.

Meadow, P., Hoare, D. S. \& Work, E. (1957). Interrelationships between lysine and $\alpha, \epsilon$-diaminopimelic acid and their derivatives and analogues in mutants of Escherichia coli. Biochemical Journal 66, 270-282.

Paulus, H. \& Gray, E. (1964). Multivalent feedback inhibition of aspartokinase in Bacillus polymyxa. Journal of Biological Chemistry 239, PC4008-4009.

Pooley, H. M. (1976). Turnover and spreading of old wall during surface growth of Bacillus subtilis. Journal of Bacteriology 125, 1127-1138.

Potvin, B. W., Kelleher, R. J. \& Gooder, H. (1975). Pyrimidine biosynthetic pathway of Bacillus subtilis. Journal of Bacteriology 123, 604-615.

Rogers, H. J. (1967). Killing of staphylococci by penicillins. Nature, London 213, 3 [-33.

Rogers, H. J. \& Forsberg, C. W. (1971). Role of autolysins in the killing of bacteria by some bactericidal antibiotics. Journal of Bacteriology' 108, 1235-1243.

Rosner, A. (1975). Control of lysine biosynthesis in Bacillus subtilis: inhibition of diaminopimelate decarboxylase by lysine. Journal of Bacteriology 121, 20-28.

Rosner, A. H. \& Paulus, H. (1971). Regulation of aspartokinase in Bacillus subtilis. The separation and properties of two isofunctional enzymes. Journal of Biological Chemistry 246, 2965-2971. 
SChaeffer, P., Millet, J. \& Aubert, J.-P. (1965). Catabolic repression of bacterial sporulation. Proceedings of the National Academy of Sciences of the United States of America 54, 704-711.

Seubert, H. \& Weiker, H. (1969). Pyruvate carboxylase from Pseudomonas. Methods in Enzymology XIII, 258-262.

Theodore, T. \& Englesberg, E. (1962). A mutant of Salmonella typhimurium deficient in carbon dioxide fixation. Bacteriological Proceedings, 117.
WARD, J. B. (1975). Peptidoglycan synthesis in L-phase variants of Bacillus licheniformis and Bacillus subtilis. Journal of Bacteriology 124, 668-678.

YouNG, M. (1975). Genetic mapping of sporulation operons in Bacillus subtilis using a thermosensitive sporulation mutant. Journal of Bacterio$\log y$ 122, 1109-1116. 